\title{
Subjective Well-Being of Portuguese Employees: The Role of Personality and Organizational Context
}

\author{
Cláudia Figueiredo ${ }^{1 *}$, Ana D. Daniel ${ }^{1}$, João Almeida ${ }^{1}$ and Sandra C. Soares ${ }^{2}$ \\ ${ }^{1}$ GOVCOOP, University of Aveiro, Aveiro Portugal \\ ${ }^{2}$ William James Center for Research, Department of Education and Psychology, University \\ of Aveiro, Aveiro, Portugal
}

\begin{tabular}{|c|c|}
\hline ARTICLE INFO & ABSTRACT \\
\hline $\begin{array}{l}\text { Keywords: } \\
\text { Subjective well-being } \\
\text { Open to Experience } \\
\text { Resilience } \\
\text { Psychological Safety } \\
\text { Active adults }\end{array}$ & $\begin{array}{l}\text { Subjective well-being (SWB) has been widely associated with } \\
\text { quality of life and health outcomes. In the organizational and } \\
\text { work context, SWB has been also related to better outcomes, } \\
\text { like higher levels of job satisfaction, productivity and enhanced } \\
\text { career development. Yet in the present context of economic } \\
\text { pressure and highly dynamic work markets employees are } \\
\text { asked to be better at taking risks to come with fast and creative } \\
\text { solutions and companies are facing the challenge of recruiting } \\
\text { best equipped individuals and assuring the conditions for them } \\
\text { to be at their best. Personal and organizational characteristics, } \\
\text { like personality and psychological safety seen to play an } \\
\text { important role in these matters. However, it is still to know how } \\
\text { are these variables associated with the employees' well-being. } \\
\text { The aim of this study is to explore the impact of open to } \\
\text { experience, resilience and psychological security on SWB. A } \\
\text { sample of } 193 \text { Portuguese adults working in } 20 \text { companies of } \\
\text { the industry and IT sectors answered a standardize } \\
\text { questionnaire. In order to explore what and to what extent } \\
\text { personal (open to experience and resilience) and organizational } \\
\text { (psychological safety) variables impact SWB the multiple } \\
\text { regression models were computed. Results showed that the } \\
\text { most associated variable in the three models is resilience and } \\
\text { that the three predictors have higher impact on explaining Life } \\
\text { Satisfaction (29.5\%) and Positive Affect (26.5\%). }\end{array}$ \\
\hline
\end{tabular}

\section{Introduction}

Research on well-being has been growing in the last decades (Dominko \& Verbič, 2018), and it has been approached from different perspectives and research fields, such as psychology, sociology, medicine and economics. A distinction is often made between eudemonic and hedonic well-being. While in the former approach well-being is defined in terms of the degree to which a person is fully functioning and a self-realized individual (Ryan \& Deci, 2001), whereas the latter is focused on subjective well-being (SWE) which is defined as multidimensional construct composed by three components: Life Satisfaction (LS), Positive Affect (PA) and Negative Affect (NA) (Diener 1984; Diener, Eunkook, Richard, \& Heidi,

* Corresponding author E-mail address: claudiafigueiredo@ua.pt 
1984). Life satisfaction is a cognitive dimension that comprises the individual subjective evaluation of one's own overall satisfaction with life. The other two dimensions encompasses an affective component which includes the perceptions on positive and negative reactions (Diener 1984; Diener and Lucas 1999). An optimal SWB has been defined as a multidimensional construct that reflects the experience of a high level of positive affect, a low level of negative affect, and a high degree of satisfaction with one's life (Deci \& Ryan, 2008; Diener, Lucas, \& Oishi 2005).

Several studies have been published regarding the relationship between well-being and several health outcomes, quality of life and job satisfaction. For instance, higher levels of SWB have been associated with health indicators like biological profile or inflammatory markers and longevity (e.g., Boehm \& Kubzansky, 2012; Diener, Pressman, Hunter, \& Delgadillo-Chase, 2017; DeNeve, Diener, Tay, \& Xuereb, 2013; Endrighi, Hamer \& Steptoe, 2011). Moreover, SWB has been related with better organizational and work variables, such as productivity, higher incomes, less unemployment or more workplace stability (e.g., Harter, Schmidt, \& Hayes, 2002; Oswald, Proto, \& Sgroi, 2015). The main focus of these studies has been on the accountability of people's SWB, which has been fuelled by the pressure for measuring wellbeing or happiness as an indicator of development and growth of nations (e.g., Diener, Oishi, \& Lucas, 2015; Thompson, Marks, Jackson, 2013).

Another research stream focused on the determinants of SWB in different contexts. Among the most studied determinates is income (Clark, Frijters, \& Shields, 2008; Easterlin, 1995), unemployment (Clark, 2003; Di Tella, MacCulloch, \& Oswald, 2001) and education (Hayo \& Seifert, 2003; Keyes, Shmotkin, \& Ryff, 2002). In the context of the employed population, there is still a limited, but relevant number of studies. In this line, Warr (1987) has identified 10 antecedents of work-related well-being, such as opportunity for control, opportunity for skill use, variety at work, opportunity for interpersonal contact, externally generated goals, environmental clarity, availability of money, physical security and a valued social position. More recently, (Guest, 2017) present a set of human resources management practices that aim at increasing employees work-related well-being. Our work aims at providing clarity in this field by exploring which individual and organizational variables have impact on the three dimensions of SWB.

This study is relevant since empirical studies have demonstrated that a high employee's wellbeing has both a direct and indirect effects on performance, through an impact on employee's attitudes, motivation and behaviour (Daniel \& Harris, 2000; Schaufeli, Bakker, \& van Rhenen, 2009).

\section{Theoretical background}

In the context of workplaces, with the increasing competition among organizations, employees are asked to be more proactive, cooperative and embrace new challenges and experiments (Grant \& Ashford, 2008; Nembhard \& Edmondson, 2011). In order to do so, employees are need to devote more energy into work, take personal risks, and at the same time not be afraid of negative consequences for their self-image, career or status (Edmondson, 2003; Kahn, 1990). These demands for employees with a set of personal characteristics, like open to experience, resilience and psychological safety.

The first two characteristics are individual variables considered as personality traits that are relatively stable and shape the ones typical mindset and behaviour.

Openness to experience is a personality facet that is part of the Five Factor Model (FFM) also known as the Big Five model and is a personal tendency for proactive seeking and appreciation of experience for its own sake as well as toleration and exploration of the unfamiliar (Costa \& McCrae 2008; McAdams \& Olson, 2010). An extensive amount of work is consistent in the associating this characteristic to SWB, in particular with the affective dimensions (e.g., 
Albuquerque et al. 2013; Diener, Oishi, \& Lucas, 2003; Grant, Langan-Fox, \& Anglim, 2009; Steel, Schmidt, \& Shultz, 2008).

Resilience is also a personal attribute that boosts individual adaptation by moderating the negative effect of demanding events. Resilience has been defined as a positive characteristic that enhances individual adaptation and moderates the negative effects of stress. It implies inner strength, optimism, flexibility and the capability to positively cope and bounce back when in the face with situations that are considered adverse and challenging (Wagnild, 2009; Wagnild \& Young, 1993Wagnild \& Collins, 2009). The role of resilience and its impact on SWB has been gaining space in the scientific literature even though it still relatively sparse (eg., Goodman, Disabato, Kashdan, \& Machell, 2016; Schltze-Lutter, Schimmelmann, \& Schmidt, 2016).

In turn, psychological safety is a characteristic that is mainly related to workplace context and can be defined as the "shared belief that the team is safe for interpersonal risk taking" (Edmondson, 1999). It is assumed to be a cognitive state that can foster, for instance, the learning and creative processes, or the organizational change, since allows employees to feel safe to speak up, to admit and learn with mistakes, to ask for help or to contribute with comments or suggestions (e.g., Edmondson \& Lei, 2014). Recent research results have been ensuring that psychologically safe teams learn more, innovate, and perform better (Edmondson \& Lei, 2014).

The aim of this study is to explore the impact of open to experience, resilience and psychological security in the three dimensions of SWB (LS, PA and NA) in a sample of Portuguese active adults.

\section{Method}

\subsection{Participants}

Participants are active adults working in 20 private companies in sectors of industry and IT services of region Centro of Portugal. The final sample had 193 participants (after excluding four outliers) with ages between 22 and 59 years old, with a mean age of 37.52 ( $\mathrm{SD}=9.89$ ), being $101(52.9 \%)$ men.

\subsection{Measures}

\subsubsection{Subjective well-being}

The Subjective well-being tripartite model of Diner (Diener 1984) was assessed using the Portuguese version of two scales: Satisfaction with life Scale - SWLS (Diener, Emmons, Larsen, \& Griffin, 1985; Portuguese version: Neto, Barros, \& Barros, 1990) and Positive and Negative Afffect Scale - PANAS (Watson, Clark, \& Tellegen, 1988; Portuguese version: Galinha \& Pais-Ribeiro, 2005).

SWLS is a 5-item instrument where participants are asked to answer in likert type response scale ranging from strongly disagree (1) to strongly agree (7). PANAS is composed by 20 items with expressions of emotional states that are to be answered in a frequency scale from 1 (very slightly or not all) to 5 (extremely).

\subsubsection{Open to experience}

Open to experience is a dimension of personality from the Big Five model and were assed in this study using a short version of 12 itens that are part of the NEO-Five Factor Inventory; (Costa \& McCrae, 1989; Portuguese version of Lima et al., 2014). The answered is asked in a 5 -point likert scale ranging from strongly disagree to strongly agree.

\subsubsection{Psychological Safety}

Psychological Safety was measured with the Team Psychological Safety questionnaire (Edmondson, 1999; Portuguese version of Ferreira, 2017). This instrument has seven items of 
unifactorial construct with Likert type response scales ranging from 1 (not apply at all) to 7 (totally applies).

\subsubsection{Resilience}

Resilience was assessed with the Resilience Scale proposed by Wagnild \& Young (1993).and adapated to portuguese adults by Pinheiro and colaborators (2015). It is a short version of 13 items with a likert response scale ranging from totally desagree (1) to totally agree (7).

\subsection{Procedure}

The procedure and instruments used in this study were approved by the institutional review boards of the University of Aveiro.

The research protocol considering the instruments presented in the previous section, was applied through paper support or online support depending on the preference of the participant. It was administrated between June and November 2019.

Informed consent was provided to the participants, which included information about the study (aims, instructions, duration, anonymity, confidentiality, and the possibility of withdrawing at any time). Also, a sociodemographic questionnaire was included to obtain data for participant's characterization.

Statistical analysis was performed using IBM SPSS 25.

\section{Results}

Three multiple regression models were computed assuming each dimension of SWB: Life satisfaction, positive affect and negative affect (Table 1). The predictors were the same in each model: Open to experience (OE), Resilience (R) and Psychological safety (PS). The same subjects were entered in the three procedures and in order to assure this symmetry the 4 outliers identified in the models were excluded from the sample.

Descriptives presented in Table 1 show levels of moderate satisfaction with life and positive affect and low negative affect. The means for open to experience, resilience and psychological safety are relatively moderate.

\begin{tabular}{lccc}
\multicolumn{5}{c}{ Table 1: Descriptive statistics for SWB dimensions and predictor variable $(\mathrm{n}=193$} \\
\hline Variables & Mean & Standard-deviation & Range \\
\hline SWB & & & \\
LS & 4.78 & 1.11 & $1-7$ \\
PA & 3.10 & 0.71 & $1-5$ \\
NA & 1.82 & 0.65 & $1-5$ \\
Predictors & & & \\
OE & 3.16 & 0.37 & $1-5$ \\
R & 5.08 & 1.05 & $1-7$ \\
PS & 5.36 & 0.77 & $1-7$ \\
\hline
\end{tabular}

The overall model of Life satisfaction (LS) is significant and explains $29.5 \%$ of variance $(\mathrm{F}(3$, $189)=26.397 ; \mathrm{p}<.001)$. The regression coefficient indicates that the three predictors have positive and significant impact on LS, being the highest impact explained by Resilience $(\beta=.353, \mathrm{t}(192)=5.414 ; \mathrm{p}<.001)$, followed by Open to experience $(\beta=.245, \mathrm{t}(192)=3.930$; $\mathrm{p}<.001)$.

The regression model for positive affect (PA) significantly explains $26.5 \%$ of total variance $(\mathrm{F}(3,189)=22,679 ; \mathrm{p}<.001)$. Only Psychological safety and Resilience are significant predictors, being the personal variable the one with the highest association $(\beta=.405$, $\mathrm{t}(192)=6.093 ; \mathrm{p}<.001)$. 
The model computed for Negative affect (NA) is significant but explains only $10.6 \%$ of variance $(\mathrm{F}(3,189)=22,679 ; \mathrm{p}<.001)$. Resilience and Psychological Safety are negative significant predictors, being the personal variable the one that accounts for the highest impact $(\beta=-.240, t(192)=3.265 ; p=.001)$.

Table 1: Regression models of subjective well-being dimensions $(n=193)$.

\begin{tabular}{|c|c|c|c|c|c|c|c|c|c|}
\hline \multirow[t]{2}{*}{ Preditor } & \multicolumn{3}{|c|}{$\mathrm{LS}$} & \multicolumn{3}{|c|}{$\mathrm{PA}$} & \multicolumn{3}{|c|}{ NA } \\
\hline & $\mathrm{R}^{2}$ & $\mathrm{~F}$ & $\mathrm{P}$ & $\mathrm{R}^{2}$ & $\mathrm{~F}$ & $\mathrm{p}$ & $\mathrm{R}^{2}$ & $\mathrm{~F}$ & $\mathrm{p}$ \\
\hline & .295 & $26.397 * *$ & & .265 & $22.679 * *$ & & .106 & $7.432 *$ & \\
\hline $\mathrm{OE}$ & & .245 & $<.001$ & & .036 & .577 & & .087 & .218 \\
\hline $\mathrm{R}$ & & .353 & $<.001$ & & .405 & $<.001$ & & -.240 & .001 \\
\hline PS & & .199 & .002 & & .210 & .002 & & -.160 & .028 \\
\hline
\end{tabular}

\section{Discussion and conclusion}

The challenging context of organizations places an increased pressure to companies and their strategies to improve recruitment processes but essentially to create condition for employees to feel safe and motivated to new challenges. These characteristics are important to better perform at work, but are also related to increase levels of subjective well-being, particularly satisfaction with life and positive affect.

The results showed an important impact of personal and organizational variables in the SWB variables, although the impact on negative affect was lower. The most important variable to impact three dimensions of SWB was resilience, followed by psychological safety. The personality facet of open to experience was only important to explain life satisfaction.

These findings reinforce the importance of acknowledging that the ability to resist and overcome negative events and the perceptions of being on safe and encouraging environment is critical to increase the levels of SWB. This conclusion is of special interest since SWB is well stablished in the literature as a condition to better health outcomes.

The participants in the present study presented relatively modest levels of SWB, especially in the dimensions of life satisfaction and positive affect. In this sense, and in order to overcome this situation, companies must increase the effort on supporting their employees.

The present study presents some limitation, namely a cross-sectional design. Therefore, it does not capture the effects of the interaction between personal and organizational variables on wellbeing measures across time. Longitudinal studies could help overcome this limitation.

Our sample has limited number of participants and focused on two specific sectors, which as it is known is an overrepresentation of a group and therefor an obstacle to the generalization of results. Therefore, future studies comprising heterogeneous and representative samples should be conducted, seeking to replicate the current findings. Future research could also encompass other personal and organizational variables that could enlarge the understanding of these associations.

\section{Acknowledgment}

This paper was developed under the support of the Research Program "CeNTER Communityled Territorial Innovation" (CENTRO-01-0145-FEDER-000002), funded by Programa Operacional Regional do Centro (CENTRO 2020), PT2020.

\section{References}

Albuquerque, I., Lima, M. P., Matos, M. \& Figueiredo, C. (2013). The interplay among levels of personality: the mediator effect of personal projects between the big five and subjective well-being. The Journal of Happiness Studies, 14(1), 235-250. 
Boehm, J. \& Kubzansky, L. (2012) The heart's content: The association between positive psychological well-being and cardiovascular health. Psychological Bulletin, 138(4), 655691.

Clark, A. E. (2003). Unemployment as a Social Norm: Psychological Evidence from Panel Data. Journal of Labor Economics, 21(2), 323-351.

Clark, A. E., Frijters, P., \& Shields, M. A. (2008). Relative income, happiness, and utility: An explanation for the Easterlin paradox and other puzzles. Journal of Economic Literature, 46(1), 95-144.

Costa, P. \& McCrae, R. (1988). The NEO-PI/FFI Manual Supplement. Odessa: Psychological Assessment Resources.

Costa, P. \& McCrae, R. (2008). The revised NEO personality inventory. In G. J. Boyle, G. Matthews \& D. H. Saklofske (Eds.), The Sage handbook of personality theory and assessment (Vol. 2, pp. 179-198). London: Sage.

Daniel, K., \& Harris, C. (2000). Work, psychological well-being and performan. Occupational Medicine, 50(5), 3004-3009.

Deci, E. \& Ryan, R. (2008). Hedonia, eudaimonia, and well-being: an introduction. Journal of Happiness Studies, 9,1-11.

DeNeve, J., Diner, E., Tay, L., \& Xuereb, C. (2013). The objective benefits of subjective wellbeing. In J. Helliwell, R. Layard, \& J. Sachs (Eds.), World happiness report 2013 (54-79). New York: Sustainable Development Solutions Network.

Di Tella, R., MacCulloch, R. J., \& Oswald, A. J. (2001). Preferences over Inflation and Unemployment: Evidence from Surveys of Happiness. American Economic Review, 91(1), 335-341.

Diener, E. (1984). Subjective well-being. Psychological Bulletin, 95, 542-575.

Diener, E., Emmons, R.A., Larson, R.J., \& Griffin, S. (1985). The satisfaction with life scale. Journal of Personality Assessment, 49, 71-75.

Diener, E., Eunkook, M. S., Richard, E. L., \& Heidi, L. S. (1984). Subjective well-being: Three decades of progress. Psychological Bulletin, 95(2), 542-575.

Diener, E., Oishi, S., \& Lucas, R. E. (2003). Personality, culture, and subjective well-being: Emotional and cognitive evaluations of life. Annual Review of Psychology, 54, 403-424.

Diener, E., Pressman, S., Hunter, J., \& Delgadillo-Chase, D. (2017). If, why, and when subjective well-being influences health, and futures needed research. Applied Psychology: Health and Well-Being, 9(2), 133-167.

Diener, E., Oishi, S., \& Lucas, R. (2015). National accounts of subjective well-being. American Psychologist, 70(3), 234-242.

Dominko, M., \& Verbič, M. (2018). The Economics of Subjective Well-Being: A Bibliometric Analysis. Journal of Happiness Studies. Published online: https://doi.org/10.1007/s10902018-0022-z

Edmondson, A. (1999). Psychological safety and learning behavior in work teams. Administrative Science Quarterly, 44(2), 350-383.

Edmondson, A. (2003). Speaking up in the operating room: How team leaders promote learning in interdisciplinary action teams. Journal of Management Studies, 40(6), 1419-1452.

Edmondson, A., \& Lei, Z. (2014). Psychological safety: The history, renaissance, and future of an interpersonal construct. Annual Review of Organizational Psychology and Organizational Behavior, 1(1), 23-43.

Endrighi, R., Hamer, M., \& Steptoe, A. (2011) Associations of trait optimism with diurnal neuroendocrine activity, cortisol responses to mental stress, and subjective stress measures in healthy men and women. Psychosomatic Medicine, 73(8),672-678.

Easterlin, R. A. (1995). Will raising the incomes of all increase the happiness of all? Journal of Economic Behavior and Organization, 27(1), 35-47 
Ferreira, M. (2017). Eficácia grupal: o papel da segurança psicológica e da aprendizagem grupal (unpublished dissertion). Coimbra: Faculty of Psychology and Educational Sciences of University of Coimbra.

Galinha, I. \& Pais-Ribeiro, J. (2005). Contribuição para o estudo da versão portuguesa da Positive and Negative Affect Schedule (PANAS): II - Estudo psicométrico. Análise Psicológica, 2(23), 219-227.

Goodman, F., Disabato, D., Kashdan, T., \& Machell, K. (2016). Personality strengths as resilience: a one-year multiwave study. Journal of Personality, 85(3), 423-434.

Grant, S., Langan-Fox, J., \& Anglim, J. (2009). The big five traits as predictors of subjective and psychological well-being. Psychological Reports, 105, 205-231.

Grant, A. \& Ashford, S. (2008). The dynamics of proactivity at work. Research in Organizational Behavior, 28, 3-34.

Guest, D. E. (2017). Human resource management and employee well-being: towards a new analytic framework. Human Resource Management Journal, published online: https://doi.org/10.1111/1748-8583.12139

Harter, J., Schmidt, F., \& Hayes, T. (2002). Business-unit level relationship between employee satisfaction, employee engagement, and business outcomes: a meta-analysis. Journal of Applied Psychology, 87, 268-279.

Hayo, B., \& Seifert, W. (2003). Subjective economic well-being in Eastern Europe. Journal of Economic Psychology, 24(3), 329-348.

Kahn, W. A. (1990). Psychological conditions of personal engagement and disengagement at work. Academy of Management Journal, 33, 692-724.

Keyes, C. L. M., Shmotkin, D., \& Ryff, C. D. (2002). Optimizing well-being: The empirical encounter of two traditions. Journal of Personality and Social Psychology, 82(6), 10071022

Lima, M. Magalhães, E., Salgueira, A., Gonzalez, A., Costa, J. Costa, M.J., \& Costa, P. (2014). A versão portuguesa do NEO-FFI: caracterização em função da idade, género e escolaridade. Psicologia, 28(2), 1-10.

McAdams, D. P., \& Olson, B. D. (2010). Personality development: Continuity and change over the life course. Annual Review of Psychology, 61, 517-542.

Nembhard, I. M., \& Edmondson, A. (2011). Psychological Safety: A Foundation for Speaking Up, Collaboration, and Experimentation in Organizations. In G. M. Spreitzer \& K. S. Cameron (Eds.), The Oxford Handbook of Positive Organizational Scholarship (pp. 490503). Oxford, UK: Oxford University Press.

Neto, F., Barros, J., \& Barros, A. (1990). Satisfação com a vida. In L. Almeida, R. Santiago, P. Silva. L. Oliveira, O. Caetano, e J. Marques (Eds.), A acção educativa: Análise psicosocial (pp. 91-100). Leiria: ESEL./APPORT.

Oswald,A., Proto, E., \& Sgroi, D. (2015). Happiness and Productivity. Journal of Labor Economics, 33(4),789-822.

Pinheiro, M. R., Matos, A.P., Pestana, C., Oliveira, S., \& Costa, J. (2015). The resilience Scale: a study in a Portuguese adult sample. The European proceedings of Social \& Behavioural Sciences, eISSN, in http://dx.doi.org/10.15405/epsbs.2015.08.7

Ryan, R. M., \& Deci, E. L. (2001). On Happiness and Human Potentials: A Review of Research on Hedonic and Eudaimonic Well-Being. Annual Review of Psychology, 52(1), 141-166.

Schaufeli, W. B., Bakker, A. B., \& van Rhenen, W. (2009). How changes in job demands and resources predict burnout, work engagement, and sickness absenteeism. Journal of Organizational Behavior, 30(7), 893-917.

Schltze-Lutter, F., Schimmelmann, B., \& Schmidt, S. (2016). Resilience, risk, mental health and well-being: associations and conceptual differences. European Child \& Adolescent Psychiatry, 25(5). 459-466. 
Steel, P., Schmidt, J., \& Shultz, J. (2008). Refining the relationship between personality and subjective wellbeing. Psychological Bulletin, 134, 138-161.

Thompson, S., Marks, N., \& Jackson, T. (2013). Well-being and sustainable development. In S. A. David, I. Boniwell, \& A. Conley Ayers (Eds.), The Oxford handbook of happiness (pp. 498-516). New York: Oxford University Press.

Wagnild, G. (2009) A Review of the Resilience Scale. Journal of Nursing Measurement, 17, 105-113.

Wagnild, G., \& Young, H. M. (1993). Development and psychometric evaluation of the Resilience Scale. Journal of Nursing Measurement, 1, 165-178.

Warr, P. B. (1987). Work, unemployment, and mental health. Oxford science publications. Retrieved from Welfare Files

Watson, D., Clark, L., \& Tellegen, A. (1988). Development and validation of brief measures of positive and negative affect: the PANAS scales. Journal of Personality and Social Psychology, 54, 1063-1070. 